NBER WORKING PAPER SERIES

\title{
CHANGES IN BUSINESS CYCLES: EVIDENCE AND EXPLANATIONS
}

\author{
Christina D. Romer
}

Working Paper 6948

http://www.nber.org/papers/w6948

\section{NATIONAL BUREAU OF ECONOMIC RESEARCH \\ 1050 Massachusetts Avenue \\ Cambridge, MA 02138 \\ February 1999}

Prepared for the Journal of Economic Perspectives. I am grateful to Brad De Long, David Romer, and Timothy Taylor for helpful comments and suggestions. Financial support was provided by the NSF and the John Simon Guggenheim Foundation. The views expressed here are those of the author and do not reflect those of the National Bureau of Economic Research.

(1) 1999 by Christina D. Romer. All rights reserved. Short sections of text, not to exceed two paragraphs, may be quoted without explicit permission provided that full credit, including ${ }^{\circledR}$ notice, is given to the source. 
Changes in Business Cycles: Evidence and Explanations

Christina D. Romer

NBER Working Paper No. 6948

February 1999

JEL No. E32, E63, N12

\begin{abstract}
This paper analyzes changes in American business cycles over the twentieth century and suggests a possible explanation for the major changes that have and have not occurred. The empirical analysis shows that the volatility of annual real macroeconomic indicators and the average severity of recessions have declined only slightly between the pre-World War I and post-World War II eras. Recessions have, however, become somewhat less frequent and more uniform. The paper goes on to suggest that the advent of macroeconomic policy after World War II can account for both the continuity and the changes in business cycles. Countercyclical monetary policy and automatic stabilizers have prolonged postwar expansions and prevented severe depressions. At the same time, policy-induced booms and recessions have led to the continued volatility of the postwar economy.
\end{abstract}

Christina D. Romer

Department of Economics

549 Evans Hall \# 3880

University of California, Berkeley

Berkeley, CA 94720-3880

and NBER

cromer@econ.berkeley.edu 
In his 1959 Presidential Address to the American Economic Association, Arthur Burns (1960, p. 1) predicted, if not the end of business cycles in the United States, at least "progress towards economic stability." The advent of stabilization policy, the end of bank runs, and structural changes in the economy all seemed destined to radically reduce short-run economic fluctuations in the postwar era. In Burns's (p. 17) words, "[T]he business cycle is unlikely to be as disturbing or troublesome to our children as it once was to our fathers." This essay analyzes to what extent Burns's prediction of growing stability in the post-World War II United States has come to pass. It also examines the reasons for continuity and change in economic fluctuations over time.

The first section of the paper presents a compilation of facts about short-run fluctuations in real economic activity in the United States since the late 1800s. I put particular emphasis on data series that I believe are consistent across the entire 20th century, and focus especially on the comparison between the periods before World War I and after World War II. The bottom line of this analysis is that economic fluctuations have changed somewhat over time, but neither as much nor in the way envisioned by Burns. Major real macroeconomic indicators have not become dramatically more stable between the pre-world War I and post-World War II eras, and recessions have become only slightly less severe on average. Recessions have, however, become less frequent 
and more uniform over time.

In the second section of the paper, I suggest a likely explanation for the changes we do and do not see in the data. In this explanation, the rise of macroeconomic policy emphasized by Burns plays a crucial role. Increasing government control of aggregate demand in the postwar era has served to damp many recessions and counteract some shocks entirely. Thus, the advent of effective aggregate demand management after World War II explains why cycles have become less frequent and less likely to mushroom. At the same time, however, there have been a series of episodes in the postwar era when monetary policy has sought to create a moderately-sized recession to reduce inflation. It is this rise of the policy-induced recession that explains why the economy has remained volatile in the postwar era. Furthermore, the replacement of the large and small shocks from a wide variety of sources that caused prewar recessions with moderate shocks from the Federal Reserve also explains why recessions have become more uniform over time.

\section{Evidence of Changes in Fluctuations}

Before delving into explanations, it is necessary to analyze the facts about stabilization in detail. Only by establishing how economic fluctuations have changed can we know the phenomena to be explained. 


\section{Volatility of Annual Movements}

A sensible first pass at the data is to look at the volatility of various annual macroeconomic indicators in different time periods. A measure such as the standard deviation of percentage changes can provide crude evidence of changes, or lack of changes, in economic fluctuations over time. It also has the virtue of being a sensible indicator within a variety of frameworks. For both aficionados of traditional business cycle frameworks and proponents of linear time-series models of fluctuations, a major change in the volatility of growth rates would signal an important change in short-run fluctuations.

The obvious series to compare over time are standard macroeconomic indicators such as real GNP, industrial production, and unemployment. Such comparisons, however, are complicated by the fact that contemporaneous data on these quantities have only been collected for part of the 20th century. For example, the Federal Reserve Board index of industrial production begins in 1919, the Commerce Department GNP series begins in 1929, and the Bureau of Labor Statistics unemployment rate series begins in 1940. Furthermore, because World War II marked a radical change in the data collection efforts of the U.S. government, many of these series are only available on a truly consistent basis after 1947.

Historical extensions of many of these series were constructed in the 1940s and 1950s. Typically, comprehensive data were only available in census years. Intercensal 
observations were estimated by interpolating with whatever fragments of data were available.

In a series of papers, I showed that this method of constructing historical macroeconomic data tended to accentuate the volatility of the early series. The source of the bias lies with the series used for interpolation. The data available for intercensal years typically cover primary commodities that were easy to measure (such as pig iron, coal, and crude oil), or states or sectors where fluctuations were perceived to be a problem. Both of these types of series are more cyclically sensitive than average. However, the interpolating techniques available in the early postwar era simply assumed that the series being constructed moved one-for-one with the bits and pieces of available data. The result is excessively volatile historical series. ${ }^{1}$

However, more consistent series can be derived. For example, in Romer (1986a), I used two methods for dealing with the fact that the unemployment series for 1900-1930 constructed by Lebergott (1964) is not consistent with the official BLS statistics after 1940. One involved constructing a postwar series using Lebergott's techniques and base data. This yields a series that is consistently bad over time. Alternatively, I constructed a new pre-1930 unemployment series by analyzing the relationship between the postwar series derived using the Lebergott approach and the unemployment series issued by the BLS. This estimated relationship was then used to filter the pre-1930 Lebergott series to form a better, though certainly still imperfect, historical extension of the modern BLS series. ${ }^{2}$ It is important to note that such a regression procedure does not force the early 
series to be as stable as the postwar series. Because the filter only removes the excess volatility due to data inconsistencies, if the historical series being filtered is highly volatile, even the corrected series could be more volatile than the postwar series.

For industrial production I used another regression procedure to yield a reasonably consistent series. ${ }^{3}$ Jeffrey Miron and I constructed a new monthly index of industrial production for 1885 to 1940 (Miron and Romer, 1990). Because of data limitations, this index is based on many fewer commodities and on goods that are much less processed than the Federal Reserve Board (FRB) index after 1919. As a result, it is substantially more volatile than the FRB index. To form a more consistent series, I regressed the FRB index on the Miron-Romer index in a period of overlap (1923-1928) and then used the estimated relationship to filter the pre-1919 Miron-Romer series. ${ }^{4}$

For GNP I also used a regression procedure to produce a more accurate historical extension to the Commerce Department series (Romer, 1989). The key source of inconsistency between the modern series and the early series constructed by Kuznets (1961) is that GNP before 1909 was assumed to move one-for-one with commodity output. In the period when good data exist on both quantities, however, real GNP is substantially more stable than commodity output because services, transportation, and the other non-commodity sectors are nearly acyclical. I therefore used the estimated relationship between real GNP and commodity output in the period 1909-1985 to transform relatively accurate pre-1909 data on commodity output into new estimates of GNP that can be compared with the modern series. ${ }^{5}$ Since the size of the commodity- 
producing sector has declined somewhat over time, I allow the estimated sensitivity of GNP to commodity output to have declined over time, thus further increasing the reliability of the pre-1909 data.

Historical series derived using regression procedures, like those described above, will inevitably be at least slightly less volatile than the true series. This is true simply because the fitted values of a regression leave out the unpredictable movements represented by the error term. For the series I derived, this over-correction is almost surely small. Because the series used for prediction are so similar to or constitute such a large portion of the series being measured, the variance of the error term in each case is very small. Even so, it is useful to compare a series that has not been adjusted by a regression. The commodity output series described above is an obvious series to consider. ${ }^{6}$ It represents a substantial fraction of total output and is available in a reasonably consistent form over the entire 20th century.

Table 1 shows the standard deviation of growth rates for the various consistent macroeconomic indicators discussed above. I compare three sample periods: 1886-1916, 1920-1940, and 1948-1997. The first period corresponds to the pre-World War I era (which I will often refer to simply as the prewar era). As I discuss in more detail in the next section, this is for all practical purposes the era before macro-policy. The second period obviously corresponds to the interwar era. For consistency, I have left out the years corresponding to both World War I and World War II. However, World War I had sufficiently little effect on the economy that including the years 1917 to 1919 in either the 
prewar or interwar eras has little impact on the results discussed in this paper. Finally, the third period corresponds to the post-World War II (or more simply, the postwar) era.

One finding that stands out from the table is the extreme volatility of the interwar period. There is simply no denying that all hell broke loose in the American economy between 1920 and 1940. For each series, the standard deviation of percentage changes is two or more times greater in the interwar period than in either the prewar or postwar eras. While this greater volatility stems mainly from the Great Depression of 1929-1933, there were also extreme movements in the early 1920s and the late 1930s. The increased volatility is most pronounced in industrial production, reflecting the particularly large toll that the Depression took on manufacturing.

A second finding that is evident in Table 1 is the rough similarity of volatility in the pre-World War I and post-World War II eras. The postwar era has not been, on average, dramatically more stable than the prewar era. Having said this, however, it is important to note that in each case the postwar standard deviation is at least slightly smaller than its prewar counterpart. Based on these four indicators, it appears that the volatility of the U.S. macroeconomy has declined 15 to 20 percent between the pre-1916 and the post-1948 eras.

An examination of the annual changes underlying the summary statistics in Table 1 shows that the similarity of standard deviations across the prewar and postwar erase does not mask some fundamental change in the underlying distributions. It is not the case, for example, that the similar standard deviations result from large recessions in the 
prewar era and large booms in the postwar era. Instead, the standard deviations are roughly similar in the two eras because the distributions of annual changes are roughly similar. The postwar standard deviations are slightly smaller than the prewar standard deviations because the postwar distributions of annual changes are slightly compressed.

This basic similarity of volatility in the prewar and postwar eras echoes findings from studies that consider different types of evidence. Sheffrin (1988) examines industrial production data from six European countries, which he argues are more likely to be consistent over time because of the earlier advent of government record keeping in Europe. He finds that, with the exception of Sweden, there has been little change in volatility between the pre-World War I and post-World War II eras in other industrial countries. Shapiro (1988) examines stock price data for the United States, on the grounds that such financial data have been recorded in a comprehensive way since the late 1800 s and should bear a systematic relationship to real output. He finds that stock prices, while exceedingly volatile in the interwar era, are roughly equally volatile in the pre-World War I and post-World War II periods.

The results reported in Table 1 also echo those from a study using disaggregate output data. While consistent aggregate data for the United States typically have to be derived using regression procedures, there exist numerous individual production series that have been collected in much the same way since the late 1800s. In a previous paper (Romer, 1991), I found that the production of particular commodities such as wheat, corn, coal, pig iron, refined sugar, and cotton textiles has not become substantially more stable 
over time. In general, the volatility of agricultural and mineral goods production has not declined at all between the prewar and postwar eras and the volatility of manufactured goods output has declined between 25 and 35 percent.

This amount of stabilization may be quite noticeable and important to the economy. However, it is small relative to the change shown by inconsistent data. Several studies in the 1970s and early 1980s reported declines in annual volatility of 50 to 75 percent (for example, Baily, 1978; De Long and Summers, 1986). Some of the most dramatic reported declines stemmed from melding the pre-World War I and the interwar eras into a single pre-World War II period. However, all of the traditional pre-World War I extensions of the modern macroeconomic indicators show a decline in the standard deviation of percentage changes of 50 percent or more.

Fairness requires that I admit that my evidence of inconsistency between preWorld War I and post-World War II data, and hence my findings on stabilization, are controversial. Balke and Gordon (1989), for example, have created an alternative prewar GNP series that is still substantially more volatile than the postwar series. While I believe their results arise from incorrect choices of interpolating series and base data, additional research is clearly needed to resolve the issue of just how much stabilization has occurred over time.

The simple passage of time may be what finally settles the issue. While the postwar era has not been, on average, much more stable than the prewar era, there may have been an important change within the postwar era. Table 2 reports standard 
deviations of percentage changes for the two subperiods 1948-1984 and 1985-1997. The first 37 years of the postwar era were on average about twice as volatile as the last 13 . While it would be foolhardy to deduce a trend from just 13 years of data -- especially considering the precarious state of the world economy in the second half of 1998 -- it is certainly possible that Burns's prediction of increasing stability is finally coming to pass.

(As a further inducement to caution, I cannot resist noting that Burns made his original prediction based on the similar, but ultimately fleeting, stability of the 1950s.)

\section{Frequency and Severity of Recessions}

It is useful to supplement the previous analysis of annual volatility with an analysis that focuses explicitly on recessions. This focus is appropriate if one believes that recessions are a particular problem for society. It is also sensible if one believes that recessions are more amenable to government control than are technological change and other sources of expansion and growth.

The fact that there are extended periods when output is generally falling is obvious to anyone who looks at macroeconomic data. However, it was Arthur Burns and Wesley Mitchell at the National Bureau of Economic Research (NBER) who undertook the more precise definition and measurement of recessions, or "contractions" as they called them (Burns and Mitchell, 1946). The result was a series of dates of peaks and troughs in economic activity for the prewar and interwar eras. This list of "reference dates" has been continued throughout the postwar era by the Business Cycle Dating Committee of 
the NBER.

In an earlier paper, I showed that the NBER's dating procedures have not been entirely consistent over time (Romer, 1994). In particular, while the post-World War II dates of peaks and troughs have been derived from aggregate indicators in levels, the prewar and interwar dates were derived, at least partially, from detrended series. Detrending a data series that is generally upward sloping, like real output, tends to produce a series that peaks earlier and troughs later than the same series in levels. This is true because growth typically slows down as output reaches its highest point and accelerates slowly from its nadir, causing the deviations from trend to be highest before the peak in levels and lowest after the trough in levels. As a result, the earlier procedure of using detrended data is likely to make pre-World War II expansions look shorter and pre-World War II recessions look longer than they would if postwar procedures had been used. $^{7}$

For this reason, I derived a new series of pre-World War II peaks and troughs. To do this, I created an algorithm based on Burns and Mitchell's guidelines that, when applied to monthly postwar data on industrial production, yielded business cycle reference dates that were nearly identical to those of the NBER. I then applied the same algorithm to the adjusted Miron-Romer industrial production index for 1885-1918 and the Federal Reserve index for 1919-1940 described above. When the new reference dates were significantly different from those of the NBER, I went back to the contemporaneous business press to check that the new dates were at least as plausible as the NBER's. The 
new prewar and interwar dates of peaks and troughs, along with the postwar NBER dates, are given in Table $3 .^{8}$

Armed with a consistent set of dates, one can analyze changes in the frequency and duration of recessions. Table 4 shows the length of time from peak to trough (recessions) and from trough to next peak (expansions) for each peak. It also reports the averages for the prewar, interwar, and postwar eras.

The first finding is that recessions have not become noticeably shorter over time. The average length of recessions is actually one month longer in the post-World War II era than in the pre-World War I era. There is also no obvious change in the distribution of the length of recessions between the prewar and postwar eras. Most recessions lasted from 6 to 12 months in both eras. Recessions were somewhat longer in the interwar era. However, an average for this period is virtually impossible to interpret since it includes the Great Depression, where 34 months elapsed between the peak and the trough. Probably the most sensible conclusion to draw for the interwar period echoes that from the previous section: the 1920s and 1930s were simply very peculiar.

A second finding is that expansions have unquestionably lengthened over time. Recessions are noticeably less frequent in the post-World War II era than in the preWorld War I era. The average time from a trough to the next peak is about 50 percent longer in the postwar period than in the prewar period. ${ }^{9}$ Not surprisingly, expansions were somewhat shorter on average during the volatile interwar period than during the prewar era. 
The greater average length of postwar expansions is due almost entirely to the fact that the postwar era has had a few very long expansions. In both the 1960s and the 1980s, the United States had expansions lasting at least 7 years. In the pre-World War I era, there was only a single impressive expansion, and it lasted just 66 months. Such long expansions have a large effect on the average. If one looks only at expansions less than 5 years long, the average postwar length is just six months longer than the average prewar length. The current experience only reinforces this trend. As of December 1998, the U.S. economy had been expanding for 93 months. Adding this additional lengthy expansion raises the average postwar length to 56.1 months, or 65 percent longer than the typical prewar expansion. Based on these findings, it appears that a move toward very long episodes of expansion is an important change in economic fluctuations over time.

By combining the dates of recessions with the monthly data on industrial production described above, it is possible to analyze the severity of downturns in different eras. The output loss in a recession is a sensible measure of severity that takes into account both the size of the peak-to-trough decline and the duration of the fall. It can be calculated as the sum of the percentage shortfall in industrial production from the peak in every month that output is below the peak. ${ }^{10}$ This measure shows the percentage-pointmonths of industrial production lost in a recession. For example, a recession in which output was 10 percent below peak for each of six months would have an output loss of 60 percentage-point-months. Table 5 shows the output loss for each recession and the average for various eras. 
Table 5 shows that the average output loss has declined only slightly between the pre-World War I and the post-World War II eras. The output loss in the typical prewar recession is approximately 6 percent larger than in the typical postwar recession. In contrast, the severity of interwar recessions is enormous compared with that of prewar and postwar recessions. The average output loss in interwar recessions was roughly six times as large as the average loss either before World War I or after World War II. While the interwar average is unquestionably dominated by the Great Depression, it is important to note that the output losses in the recessions of both 1920 and 1937 were much larger than any in the prewar or postwar eras.

Looking at the distribution of output loss reveals a subtle, but I think important, change over time. Average output loss may be roughly the same in the pre-World War I and post-World War II eras, but recessions have become more concentrated in the moderate range. Figure 1 plots the output loss in the nine prewar and nine postwar recessions, where the recessions within each era have been ordered from smallest to largest. This graph shows that the smallest recessions had lower output losses and the largest recessions had higher output losses in the prewar era than in the postwar era. Output loss in recessions has thus been more uniform in the postwar era than in the prewar era.

These findings about changes in the frequency and severity of recessions both reinforce and illuminate the findings on annual volatility. The fact that recessions have become less frequent and slightly less severe on average between the prewar and postwar 
eras is consistent with the fact that annual volatility has declined slightly over time. The fact that the most severe postwar recessions are not quite as large as the most severe prewar recessions is also consistent with modest stabilization.

At the same time, the fact that the distribution of output loss has changed over time can explain why annual volatility has declined only slightly, despite the marked increase in the length of expansions. The wider range of prewar cycles means that there were noticeably more small cycles in the prewar era than in the postwar era. These small prewar cycles had a substantial impact on the length of prewar expansions, but contributed relatively little to annual volatility. Fundamentally, the postwar era is nearly as volatile as the prewar era because we have continued to have a similar number of significant recessions.

\section{A Possible Explanation}

The bottom line of the previous analysis is that short-run fluctuations have changed in some ways over time and have remained fundamentally similar in others. What has not changed, at least not dramatically, between the prewar and postwar eras is the volatility of broad macroeconomic indicators and the average severity of recessions. 
Both annual movements and recessions have been damped only modestly over time. One caveat to this conclusion is the possibility that a trend toward much greater stability may be becoming apparent in the last 10 to 15 years. What has changed between the prewar and postwar eras is the frequency and distribution of recessions. Expansions are noticeably longer after World War II than before World War I, indicating that recessions happen less often today than in the past. Also, recessions, while not less severe on average in the postwar era, do appear to be somewhat more clustered in the moderate range.

The most likely source of both the continuity and the change in economic fluctuations is the rise of macroeconomic policy after World War II. In the post-World War II period, macroeconomic policy and related reforms have eliminated or damped many of the shocks that caused recessions in the past, and thus brought about longer expansions and fewer severe recessions. But postwar macro-policy has introduced other shocks. It is the rise of policy-induced recessions undertaken to reduce inflation in the postwar era that explains the essential similarity of cyclical severity and volatility over time. In short, it is the fact that we have replaced uncontrolled random shocks from a wide variety of sources with controlled policy shocks that explains the changes we do and do not see in fluctuations over time.

\section{The Rise of Macroeconomic Policy}

The changes that have occurred in macroeconomic policy over time can hardly be 
exaggerated. Before 1916 it was practically impossible for the U.S. government to affect the macroeconomy through conventional aggregate demand channels. Taxes and government spending in the prewar era were so small that plausible variations in fiscal policy could neither cause nor dampen significant fluctuations. For example, the ratio of federal government expenditures to GNP was between just $11 / 2$ to $21 / 2$ percent in almost every year between 1901-1916. ${ }^{11}$ De Long (1998) shows that the government budget surplus (or deficit) was also small and virtually constant throughout the prewar era.

The government in the prewar era clearly had some effect on the economy through the choice of monetary standard and banking regulation. However, until the founding of the Federal Reserve in 1914, the United States did not possess an institution able to effect substantial short-run movements in interest rates. Indeed, since the Federal Reserve took a few years to begin operations, it is reasonable to say that monetary policy as we mean it today did not exist before World War I.

The interwar era can best be thought of as the transition period between no government control and effective government control of aggregate demand. Federal government spending increased substantially during World War I, from less than 2 percent of GNP in 1915 to 20 percent in 1918. While the size of government spending shrank again in the 1920s, it never returned to prewar levels. Furthermore, the World War I experience established a precedent for significant government spending. In the mid-1930s government expenditures as a fraction of GNP rose to over 10 percent, 
causing the average interwar ratio to be just over 6 percent.

The Federal Reserve also began to exert considerable influence after World War I. For example, Friedman and Schwartz (1963) argue that the Federal Reserve's decision to raise the discount rate dramatically in 1919 and 1920 precipitated the recession of 1921. There are, of course, numerous debates about the wisdom of the Federal Reserve's actions in the interwar era and the degree to which monetary policy was constrained by the gold standard. But it is reasonably clear that monetary policy first arose as an important cyclical force -- for good or ill -- in the 1920s and 1930s.

By the start of the postwar era, both the ability and the will to use policy to manage aggregate demand were firmly established. World War II appears to have brought about another permanent ratcheting up of government spending and taxes. For example, for most of the postwar era federal government expenditures have been between 15 and 20 percent of GNP. Postwar increases in state and local government spending mean that the rise in total government spending has been even more dramatic.

During and immediately following World War II, the Federal Reserve felt obligated to support the price of government securities, in essence keeping the nominal interest rate low and nearly constant. The Treasury-Federal Reserve Accord of 1951 abolished this obligation and thus paved the way for the rise of independent discretionary monetary policy. The Federal Reserve began to use its new-found freedom early in the 1950s. Both the actions of the Federal Reserve in the 1950s and the record of discussions within the Federal Open Market Committee make it clear that the Federal Reserve felt an 
obligation to respond to economic developments in a way it had not in the 1930s.

There is more debate about when the concept of using fiscal policy to manage aggregate demand became widespread. The Employment Act of 1946 certainly enunciated the basic principle. During the recessions of 1953 and 1957, modest changes in government spending were made explicitly to aid recovery (Romer and Romer, 1994a). However, Stein (1969) suggests that it was not until the early 1960s that the notion of significant countercyclical fiscal action was firmly established.

In addition to the rise of discretionary government control over aggregate demand, the postwar era has also witnessed other policy changes that have affected short-run fluctuations. One is the rise of automatic stabilizers. The emergence of a significant income tax during and after World War II has made government revenues substantially procyclical; the emergence of unemployment compensation in the 1930s and the evolution of federal and state welfare programs between the 1930s and the 1960s have led government spending to have a noticeable automatically countercyclical component. These two features have yielded an actual government budget surplus that is decidedly procyclical in the postwar era.

The development of deposit insurance is another important policy change. The Federal Deposit Insurance Corporation (FDIC) was set up on a temporary basis in 1934 and achieved its more-or-less-permanent form in 1935. By insuring bank deposits, the FDIC has largely eliminated the fear that bank insolvency could lead to severe individual losses, and thus reduced the possibility of bank runs and stabilized the financial system. 
The evolution of macroeconomic policy makes clear when policy could have played a role and when it could not. Because neither the concept nor the practice of demand management existed before World War I, policy could not have played a deliberate role in causing or curing recessions at that time. ${ }^{12}$ After World War II, in contrast, macroeconomic policy not only existed, but was used with zeal. It most surely could have affected the nature of economic fluctuations. Whether this rise of policy explains the changes we observe over time depends on just how this potent tool has been used since World War II.

\section{The Beneficial Effects of Postwar Policy}

The rise of aggregate demand management and other reforms have had some beneficial effects on postwar fluctuations. In a previous study, David Romer and I sought to quantify the effects of postwar policy, especially around troughs in economic activity (Romer and Romer, 1994a). We began with simple indicators of aggregate demand policy. For monetary policy we used the change in the real federal funds rate; for discretionary fiscal policy we used the change in the ratio of the high-employment budget surplus to GDP. We then used policy multipliers from both our own regressions and conventional forecasting models to deduce the contribution of policy in particular years.

Our key finding was that monetary actions taken after the peak in activity -- that is, after the economy had turned down -- accounted for a substantial fraction of the output growth that occurred in the year following troughs. For example, using policy multipliers 
from the Data Resources, Incorporated (DRI) forecasting model, we calculated that monetary policy contributed 1.5 percentage points to the growth rate of real output in the year following a trough, while discretionary fiscal policy contributed 0.5 percentage points. This is compared with an average actual growth rate in the year following troughs of 4.6 percent. These findings suggest that stabilization policy, especially monetary policy, has played an important role in controlling the size of postwar recessions.

This finding is consistent with what the Federal Reserve said it was trying to do in these periods. A review of the narrative record shows that in nearly every postwar recession, the Federal Reserve eventually adopted active expansion in an attempt to end or ameliorate the recession. For example, a few months before the trough in 1970, the view of the Federal Open Market Committee (FOMC) was that "monetary policy at present should be sufficiently stimulative to foster moderate growth in real economic activity" (Board of Governors, 1970, p. 149) Similarly, in July 1982, the FOMC said that it wanted "to provide sufficient monetary growth to encourage recovery in economic activity over the months ahead" (Board of Governors, 1982, pp. 109-110).

Our study also looked at the effects of discretionary policy in years other than those following troughs. The findings concerning the general effects of discretionary policy are summarized in Figure 2. The solid line shows the actual change in real GDP and the dotted line shows the estimated change under neutral policy, which is defined in this case to be no change in either the real federal funds rate or in the ratio of the highemployment surplus to GDP. ${ }^{13}$ The fact that the dotted line is often below the solid line 
on downticks suggests that policy was countering some periods of low or falling output. Furthermore, there are some periods of robust expansion, such as the early 1960s and the early-to-mid 1990s, which in the absence of policy would have been episodes of very low growth. This suggests that policy may have prevented some recessions or near-recessions in the postwar era.

This sense that policy has counteracted some postwar shocks is borne out by detailed case studies. For example, Bernanke (1990) argues that interest rate cuts and other actions by the Federal Reserve following the stock market crash of 1987 prevented a significant financial crisis and the real contraction that would likely have resulted. While these monetary actions were too short-lived to show up in Figure 2, Bernanke is convincing that they had a substantial beneficial effect.

The same methods described above to look at the contribution of discretionary policy can be used to analyze the contribution of automatic fiscal stabilizers. The automatic piece of the budget surplus is the difference between the actual surplus and the high-employment surplus. The change in the ratio of the automatic surplus to GDP times the dynamic multiplier for fiscal policy gives an estimate of the effect of the automatic component of policy on real output growth.

Based on the multipliers for the DRI model, we found that automatic stabilizers contributed on average 0.85 percentage points to the real growth rate in the year following troughs; estimates based on multipliers from other models are somewhat smaller. Thus, the beneficial effects of automatic stabilizers in recessions were larger 
than those for discretionary fiscal policy, but substantially smaller than those for monetary policy. Looking more generally at the effects of automatic stabilizers reveals just what one would expect: automatic changes in the surplus have moderated both upticks and downticks in real growth. The effect, while not large, is certainly not trivial. In years of extreme rises or falls in output, automatic stabilizers reduced the absolute value of the growth rate by 1 to $11 / 2$ percentage points; in years of more moderate change, the effect was closer to $1 / 2$ percentage point. This suggests that automatic stabilizers were a source of some stabilization in the postwar era.

Deducing the contribution of deposit insurance to postwar stabilization is a topic worthy of a paper in its own right. However, the obvious starting point is the observation that financial panics were ubiquitous before World War I and almost nonexistent since World War II. According to Kemmerer (1910), there were major panics in 1890, 1893, $1899,1901,1903$, and 1907. A comparison of these dates with the dates of peaks in Table 3 confirms that there is a correlation between panics and recessions in the prewar era. Even if panics did not initiate recessions, it is likely that they exacerbated them. ${ }^{14}$ In this way, the existence of panics before deposit insurance and their disappearance after seem a likely source of at least some stabilization over time. If panics were the genuine cause of some prewar recessions, their elimination could also explain the decreasing frequency of recessions after World War II.

This analysis of the beneficial effects of policy in the postwar era suggests an answer to the question: "Why have cycles changed somewhat over time?" 
Macroeconomic variables have become slightly more stable and recessions have become slightly less severe in the postwar era because policy has systematically counteracted some shocks. Both monetary policy and automatic fiscal policy have served to moderate postwar recessions.

Recessions have become less frequent because of policy as well. Monetary policy and deposit insurance may have effectively eliminated one source of shocks in the postwar era. Furthermore, both automatic stabilizers and active policy have converted some periods of likely recession into periods of normal growth. In this way, policy almost surely explains why expansions have been longer after 1948 than before 1916 .

\section{Policy-Induced Recessions}

While the rise of macroeconomic policy and related reforms can explain the changes in fluctuations we observe, government control of postwar aggregate demand also is the key to why cycles have not changed more between the prewar and postwar eras. In the previous section, when I presented estimates of the contribution of discretionary policy in the postwar era, I focused on the times when policy stabilized output. However, Figure 2 makes it clear that there are years, such as 1981, when policy caused rather than ameliorated recessions. The rise of such policy-induced recessions explains why output and related macroeconomic indicators have not stabilized dramatically over time. At the same time, the fact that policy-induced recessions have not been allowed to mushroom explains why postwar cycles have been somewhat 
clustered in the moderate range.

Sorting out the role of policy in causing recessions is inherently difficult.

Simulations such as those in Figure 2 are one approach, but they have clear limitations. Most obviously, they take the effects of policy as given, despite the fact that the effects of policy, especially monetary policy, is a subject of much debate. Empirical findings that changes in money or interest rates are correlated with changes in output or unemployment cannot establish causation. It could be that policy responds to the state of the economy, rather than the other way around.

In our paper "Does Monetary Policy Matter?," David Romer and I (1989) sought to deal with the causation problem in estimating the effects of monetary policy by bringing in additional information. ${ }^{15}$ We read the Minutes of the Federal Open Market Committee (FOMC) and the briefer Record of Policy Actions to deduce what the Federal Reserve was trying to do and why. We found seven occasions in the postwar era when the Federal Reserve deliberately reduced aggregate demand because the prevailing rate of inflation was deemed unacceptable: in October 1947, September 1955, December 1968, April 1974, August 1978, October 1979, and December 1988. For example, in September 1955, the FOMC voted for the "maintenance of, and preferably some slight increase in, the restraining pressure it had been exerting through open market operations" because "price advances were occurring in considerable numbers" (Board of Governors, 1955, p. 105). Though the Federal Reserve naturally did not say it was trying to cause a recession, in each of these episodes it was clearly willing to accept output losses to 
reduce inflation. A few months following the 1955 decision, for example, the FOMC expressed the view that it should "combat an inflationary cost-price spiral" despite the "risk of incurring temporary unemployment" (Board of Governors, 1956, p. 26).

To estimate the effects of such policy actions, we specified a dummy variable equal to one in the months when the decision to act to reduce inflation became obvious. We then regressed the change in industrial production on many lags of the dummy variable and on control variables such as seasonal dummies and lagged industrial production. In some specifications we included additional control variables, such as the change in oil prices, to account for supply shocks. We found that decisions by the Federal Reserve to reduce aggregate demand to lower inflation led to substantial and sustained drops in industrial production; indeed, such a decision had a peak cumulative effect on the level of industrial production of approximately - 12 percent after 33 months. ${ }^{16}$

The original focus of this analysis was to test whether monetary policy mattered. Once the effects have been estimated, however, one can turn them around to see how different economic performance would have been without the decisions by the Federal Reserve. To do this, I take our estimates of the response of the change in industrial production to the monetary policy dummy variable and subtract it from the actual change in industrial production following contractionary monetary shocks. This yields a series showing the change in industrial production without deliberate monetary contractions. Table 6 presents a comparison of this simulated series with the actual changes in 
industrial production (both summed to yield annual values) in recession years. The nine postwar recessions identified in Table 3 show up in annual industrial production data as seven episodes where industrial production fell over a single year, and one episode (1979-1982) where it fell for four consecutive years. Table 6 reports these years when industrial production fell and the magnitude of each fall. It also reports whether there was a monetary shock before the downturn, and the change in the simulated industrial production series in the downturn year.

Table 6 shows that there were monetary policy shocks in all but two postwar downturns (1953 and 1960). More importantly, the behavior of the simulated industrial production series shows that, in the absence of monetary policy shocks, industrial production would have risen, rather than fallen as it actually did, in 1949, 1979, 1979-82, and 1990. In both 1957 and 1974, output would still have fallen in the absence of the monetary policy changes, but by much less. Averaged over the 11 downturn years, industrial production would have been virtually constant in the absence of monetary shocks, rather than falling over 4 percent. This suggests that contractionary monetary shocks account for a substantial share of postwar recessions.

These results suggest that the existence of policy-induced recessions in the postwar era explains why we have not seen a dramatic stabilization over time. We still have recessions after World War II, despite the rise of demand management and structural reforms, largely because policy has generated them. Average severity of recessions has declined only slightly because the average size of the recessions we have created is not 
much smaller than the average of the wide range of small, medium, and large prewar recessions. Likewise, annual volatility has not decline markedly because there are still substantial downturns in the postwar era.

Policy-induced recessions can also account for the tendency for cycles to be more uniform in the postwar era. The Federal Reserve has needed to create recessions with enough output loss to reduce inflation. ${ }^{17}$ This explains why postwar recessions have not been very small. But as discussed earlier, these policy-induced recessions have not gone unchecked. The fact that we have not observed deflation in the postwar era suggests that recessions have not been more severe than necessary to keep inflation in check, and that the Federal Reserve has stopped recessions before they reached the extreme severity of the worst prewar and interwar recessions. Cycles have thus become more clustered in the moderate range because policy has made them that way.

\section{Inflation and Policy Mistakes}

Showing that policy-induced recessions to reduce inflation account for the continued volatility of the postwar era only pushes the mystery back a step. Why has inflation been a persistent problem in the post-World War II era, at least up until 1985 ?

At some fundamental level, policy mistakes have to be key. Monetary and fiscal policy have been available and fairly well-understood since World War II. As a result, 
policy most certainly could have restrained inflation before it reached unacceptable levels. That it did not on several occasions in the postwar era indicates errors of at least omission, if not of commission.

The nature of the policy mistakes, however, seems to have evolved over time. In the late 1940s, the Federal Reserve let inflation accelerate in part because of the wartime policy of keeping interest rates low to facilitate management of the unprecedented national debt. Chandler (1951) suggests that the Federal Reserve did not press for an end to this policy because it, like most other observers, feared that the Depression would return at the end of World War II. Similar factors were at work during the Korean War, when a rapid increase in government spending combined with an unwillingness of the Federal Reserve to complicate Treasury financing of the war led to a year of high inflation. Thus, inflation in the early postwar period was the result of unique budgetary conditions and mistaken forecasts.

Most of the rest of the inflation of the 1950s appears to have been largely accidental. The Federal Reserve was genuinely aiming at price stability and attempting to restrain aggregate demand starting in 1955 . It simply missed its target for a while because of outdated operating procedures and a misunderstanding of developing conditions. $^{18}$

The policy mistakes behind the inflation of the late 1960s and 1970s appear to be a different beast. Rather than being acts of omission based on inexperience or common misperceptions, the mistakes of the 1960s and 1970s appear to be more systematic and 
willful. The simulation in Figure 2 shows that in both the mid-1960s and the early 1970s discretionary policy was decidedly expansionary, despite the fact that output growth was already high and inflation was relatively high and rising. ${ }^{19}$ In the mid-1960s, increases in government spending related to the Vietnam War and the Great Society played the key role, with monetary policy mainly failing to restrain aggregate demand growth. In the early 1970s, monetary policy was extremely stimulative, with fiscal policy playing a secondary role.

The source of these deliberate expansions and inadequate restraint in the face of high growth and rising inflation is a topic of some debate. De Long (1997) stresses historical accidents and a lingering fear of recession stemming from the Great Depression as the source of over-expansion. Taylor (1997), commenting on De Long's arguments, suggests that the mistaken economic theories of the early 1960s -- in particular, the static Phillips curve model of Samuelson and Solow -- deserve considerable blame. Fiscal and monetary policymakers may have over-expanded simply because they did not understand the trade-offs they faced. Finally, political scientists such as Tufte (1978) suggest that the 1971-72 expansion was simply the political business cycle at its most brazen. Whatever the ultimate cause, the fact is that macroeconomic policy was decidedly overly expansionary at several points in the 1960s and 70s and this policy stimulation led to rapidly rising output and inflation.

Judging from Figure 2, policy was again overly expansionary in the mid-1980s. However, the magnitude of the mistake was substantially smaller than in the 1960s and 
1970s. Policy was only mildly expansionary and inflation, though rising, was still low.

Indeed, the error is small enough that it seems likely to have been the result of idiosyncratic factors and minor miscalculations, rather than the result of the deeper factors cited for the mistakes of the previous two decades.

The implication of this discussion is that the source of the continued volatility of the postwar economy rests both superficially and fundamentally with policy. Recessions have continued in the postwar era because we have created them to reduce inflation. Inflation has been a persistent problem in the postwar era because policy, especially monetary policy, has tended to be overly expansionary. Overly expansionary policy has generated periods of rapid growth in the postwar era that have fueled price increases. In essence, we have replaced the prewar boom-bust cycle driven by animal spirits and financial panics with a postwar boom-bust cycle driven by policy.

\section{A "New Economy"?}

As discussed above, the last decade or so has been remarkably more stable than the eight or nine decades that preceded it. The late 1980s and the 1990s have also been an era of very low inflation. The explanation I have advanced for general postwar volatility suggests that these two factors are related. Macroeconomic indicators have 
been stable and recessions few since 1985 because inflation has been firmly under control. Policy has not generated bouts of severe inflation and so has not had to generate bouts of recession to control it.

Does this mean that there really is a "new economy" today where cycles are largely nonexistent? Perhaps. We have had the potential for greater stability since the advent of aggregate demand policy, automatic stabilizers, and deposit insurance. In the last decade or so we have used these tools to counteract shocks and have not created new ones. As long as policy continues to make few mistakes toward over-expansion, policyinduced recessions to control inflation should continue to be rare.

But describing the source of the change in this way makes it clear that the trend toward greater stability could be quickly reversed. The "new economy" is not the inevitable result of structural changes, globalization, or the information revolution; instead, it has emerged because we have had a steadier hand on the macroeconomic tiller in recent years than in the years before. Whether the management of aggregate demand has been steadier because of new economic theories, the skill of particular policymakers, or a new consensus about the goals of policy is hard to say. What is clear is that, replace that steady hand with an unsteady one, and the old economy could re-emerge in a flash. 


\section{References}

Allen, Steven G., "Changes in the Cyclical Sensitivity of Wages in the United States, 1891-1987," American Economic Review, March 1992, 82, 122-140.

Baily, Martin Neil, "Stabilization Policy and Private Economic Behavior," Brookings Papers on Economic Activity, 1978:1, 11-59.

Balke, Nathan S., and Robert J. Gordon, "The Estimation of Prewar Gross National Product: Methodology and New Evidence," Journal of Political Economy, February 1989, 97, 38-92.

Bernanke, Ben S., "Clearing and Settlement during the Crash," The Review of Financial Studies, Spring 1990, $\underline{3}, 133-151$.

Brunner, Karl, and Allan H. Meltzer, The Federal Reserve's Attachment to the Free Reserves Concept. Staff analysis, House Committee on Banking and Currency, 99th Congress, 2d Session, 1964.

Burns, Arthur F., "Progress Towards Economic Stability," American Economic

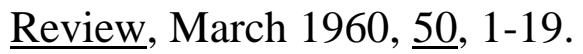

Burns, Arthur F., and Wesley C. Mitchell, Measuring Business Cycles. New York: NBER, 1946.

Calomiris, Charles W., and R. Glenn Hubbard, "Price Flexibility, Credit Availability, and Economic Fluctuations: Evidence from the United States, 1894-1909," Quarterly Journal of Economics, August 1989, 104, 429-452.

Chandler, Lester V., Inflation in the United States: 1940-1948. New York: Harper and Brothers, 1951.

De Long, J. Bradford, "America's Peacetime Inflation: The 1970s." In Romer, Christina D., and David H. Romer, eds., Reducing Inflation: Motivation and Strategy. Chicago: University of Chicago Press for NBER, 1997, pp. 247-280.

De Long, J. Bradford, "Fiscal Policy in the Shadow of the Great Depression." In Bordo, Michael D., Claudia Goldin, and Eugene N. White, eds., The Defining Moment: The Great Depression and the American Economy in the Twentieth Century. Chicago: 
University of Chicago Press for NBER, 1998, pp. 67-85.

De Long, J. Bradford, and Lawrence H. Summers, "The Changing Cyclical Variability of Economic Activity in the United States." In Gordon, Robert J., ed., The American Business Cycle: Continuity and Change. Chicago: University of Chicago Press for NBER, 1986, pp. 679-734.

Diebold, Francis X., and Glenn D. Rudebusch, "Have Postwar Economic Fluctuations Been Stabilized?" American Economic Review, September 1992, 2, 9931005 .

Economic Report of the President, 1990.

Friedman, Milton, and Anna J. Schwartz, A Monetary History of the United States, 1867-1960. Princeton, NJ: Princeton University Press for NBER, 1963.

Hanes, Christopher, "Degrees of Processing and Changes in the Cyclical Behavior of Prices in the United States, 1869-1990," Journal of Money, Credit, and Banking, forthcoming.

Kemmerer, E. W., Seasonal Variations in the Relative Demand for Money and Capital in the United States. National Monetary Commission, Senate Document 588, 61st Congress, 2d. Session, 1910.

Kuznets, Simon S., Capital in the American Economy: Its Formation and Financing. Princeton, NJ: Princeton University Press for NBER, 1961.

Lebergott, Stanley, Manpower in Economic Growth: The United States Record Since 1800. New York: McGraw-Hill, 1964.

Miron, Jeffrey A., and Christina D. Romer, "A New Monthly Index of Industrial Production, 1884-1940," Journal of Economic History, June 1990, 50, 321-337.

Moore, Geoffrey H., and Victor Zarnowitz, "The Development and Role of the National Bureau of Economic Research's Business Cycle Chronologies." In Gordon, Robert J., ed., The American Business Cycle: Continuity and Change. Chicago: University of Chicago Press for NBER, 1986, pp. 735-779.

Romer, Christina D., "Spurious Volatility in Historical Unemployment Data," Journal of Political Economy, February 1986, 94, 1-37. (a) 
Romer, Christina D., "Is the Stabilization of the Postwar Economy a Figment of the Data?," American Economic Review, June 1986, 76, 314-334. (b)

Romer, Christina D., "The Prewar Business Cycle Reconsidered: New Estimates of Gross National Product, 1869-1908," Journal of Political Economy, February 1989, 97, 1-37.

Romer, Christina D., "The Cyclical Behavior of Individual Production Series, 1889-1984," Quarterly Journal of Economics, February 1991, 106, 1-31.

Romer, Christina D., "Remeasuring Business Cycles," Journal of Economic History, September 1994, 54, 573-609.

Romer, Christina D., and David H. Romer, "Does Monetary Policy Matter? A New Test in the Spirit of Friedman and Schwartz," NBER Macroeconomics Annual, $1989, \underline{4}, 121-170$.

Romer, Christina D., and David H. Romer, "What Ends Recessions?," NBER Macroeconomics Annual, 1994, 9, 13-57. (a)

Romer, Christina D., and David H. Romer, "Monetary Policy Matters," Journal of Monetary Economics, August 1994, 33, 75-88. (b)

Shapiro, Matthew D., "The Stabilization of the U.S. Economy: Evidence from the Stock Market," American Economic Review, December 1988, 78, 1067-1079.

Shapiro, Matthew D., "Federal Reserve Policy: Cause and Effect." In Mankiw, N. Gregory, ed., Monetary Policy. Chicago: University of Chicago Press for NBER, 1994, pp. 307-332.

Sheffrin, Steven M., "Have Economic Fluctuations Been Dampened? A Look at Evidence Outside the United States," Journal of Monetary Economics, January 1988, 21, 73-83.

Stein, Herbert, The Fiscal Revolution in America. Chicago: University of Chicago Press, 1969.

Survey of Current Business, various issues. 
Taylor, John B., "Comment." In Romer, Christina D., and David H. Romer, eds., Reducing Inflation: Motivation and Strategy. Chicago: University of Chicago Press for NBER, 1997, pp. 276-280.

Taylor, John B., "An Historical Analysis of Monetary Policy Rules." In Taylor, John B., ed. Monetary Policy Rules. Chicago: University of Chicago Press for NBER, forthcoming.

Temin, Peter, "The Causes of American Business Cycles: An Essay in Economic Historiography." In Beyond Shocks: What Causes Business Cycles? Conference Series No. 42. Boston: Federal Reserve Bank of Boston, forthcoming.

Tufte, Edward R., Political Control of the Economy. Princeton, NJ: Princeton University Press, 1978.

U. S. Board of Governors of the Federal Reserve System, Annual Report. Washington, D.C.: Board of Governors of the Federal Reserve System, 1955, 1956, 1970, and 1982.

U.S. Office of Management and Budget, The Budget of the United States Government, Fiscal Year 1997, Historical Tables. Washington: U.S. G.P.O, 1996.

Watson, Mark, "Business Cycle Durations and Postwar Stabilization of the U.S. Economy," American Economic Review, March 1994, 4, 24-46. 


\section{Notes}

1. Recent studies have shown that historical price and wage series also suffer from excess volatility. Hanes (forthcoming) finds that early wholesale price data are excessively cyclical because of an over-reliance on materials prices. Allen (1992) shows that the commonly-used Rees series on average hourly earnings before 1919 overstates cyclical movements because the employment series used in the denominator is too smooth.

2. The filtered prewar unemployment series is given in Romer (1986a, Table 9, p. 31). The modern series that I consider is the unemployment rate for all civilian workers age 16 and over. The series is available as series LFU21000000 in the Bureau of Labor Statistics online databank (accessed via www.bls.gov).

3. In Romer (1986b), I used another method for constructing a consistent industrial production series, analogous to that described for unemployment. I constructed a postwar industrial production series using the same limited data on primary commodities available for the prewar era. The results of using consistently bad industrial production series in volatility comparisons are similar to those using the adjusted Miron-Romer series, so I only report the latter.

4. See Romer (1994, pp. 606-607) for a more detailed discussion of the adjustment procedures. The modern FRB industrial production series is available from the Board of Governor's website (www.bog.frb.fed.us). I use series B50001 from the seasonally unadjusted historical databank, and then seasonally adjust it using a regression on seasonal dummies. This method allows me to seasonally adjust the prewar and postwar series in the same way.

5. The new historical series is given in Romer (1989, Table 2, pp. 22-23). The modern series that I consider is the Commerce Department real GNP series in chained (1992) dollars, which is available in the Survey of Current Business (August 1998, Table 2A, pp. 151-152).

6. The prewar commodity output data are from Kuznets (1961, Table R-21. p. 553). The best postwar extension of this series is the sum of real GDP in manufacturing, mining, and agriculture, forestry, and fishing. These postwar series for 1947-1977 are available in the Economic Report of the President (1990, Table C-11, p. 307). The extensions for 1977-1996 are available in the Survey of Current Business (November 1997, Table 12, pp. 32). Because the pre-1977 series are in 1982 dollars and the post-1977 series are in chained (1992) dollars, I combine the two postwar variants of each series with a ratio splice in 1977.

7. Watson (1994) analyzes other possible inconsistencies in the NBER reference dates. 
8. Because the dates derived from the algorithm for the post-World War II era are, by construction, almost identical to the NBER dates, I see no reason for maintaining two sets of postwar dates. For this reason, I use the NBER dates for the period since 1948.

9. Moore and Zarnowitz (1986) and Diebold and Rudebusch (1992) show that this trend toward longer expansions is also evident in the original NBER reference dates.

10. Because of various nuances in the NBER dating procedures, the dated peaks are often a few months later than the actual highs in the industrial production series. In calculating the output loss, I use the shortfall from the absolute peak rather than from the dated peak. I also include any months between the absolute peak and the dated peak. The results are robust to sensible variations such as beginning at the dated peak or using the level of industrial production at the dated peak as the baseline.

11. The data on nominal federal outlays are from the Office of Management and Budget (1996, Table 1.1, p. 19). Because the expenditure data are for fiscal years, I take an appropriately weighted average of the fiscal-year estimates to convert them to an approximate calendar-year basis. The data on nominal GNP for 1901-1928 are from Romer (1989, Table 2, pp. 22-23); those for 1929-1995 are from the Survey of Current Business (August 1998, Table 1, pp. 147-148). The two GNP series are joined with a ratio splice in 1929.

12. Temin (forthcoming) shows that the causes of pre-World War I recessions given in the literature stress a wide variety of non-policy factors, such as bank runs and international monetary stringency.

13. Other plausible specifications of neutral policy yield similar results. The original calculations were based on quarterly data. To increase legibility, I have converted the estimates to annual values by summing the quarterly changes over each year.

14. De Long and Summers (1986) point out that the effects of panics may be somewhat limited because the impact on interest rates and other financial variables was typically small and short-lived. Calomiris and Hubbard (1989), however, argue that the effects working through the availability of credit may have been substantial.

15. This work was expanded and updated in Romer and Romer (1994b).

16. The estimated impulse response function of the change in industrial production to a decision to contract is roughly zero for the first five months after the shock, significantly negative in almost every month between 6 and 33 months after the shock, and then positive in months 34 to 36 after the shock. By 36 months after the shock, the effects on the change in industrial production are small. 
17. Shapiro (1994) shows that the monetary policy shocks succeeded in reducing inflation, though the effects varied substantially from episode to episode.

18. Brunner and Meltzer (1964) describe how an emphasis on free reserves in Federal Reserve operating procedures led to undesirable outcomes in the 1950s and early 1960s.

19. Taylor (forthcoming) shows that the Federal Reserve set interest rates in the late 1960s and early 1970s much lower than would be chosen by Taylor's preferred monetary policy rule. 
Figure 1

Output Loss by Rank

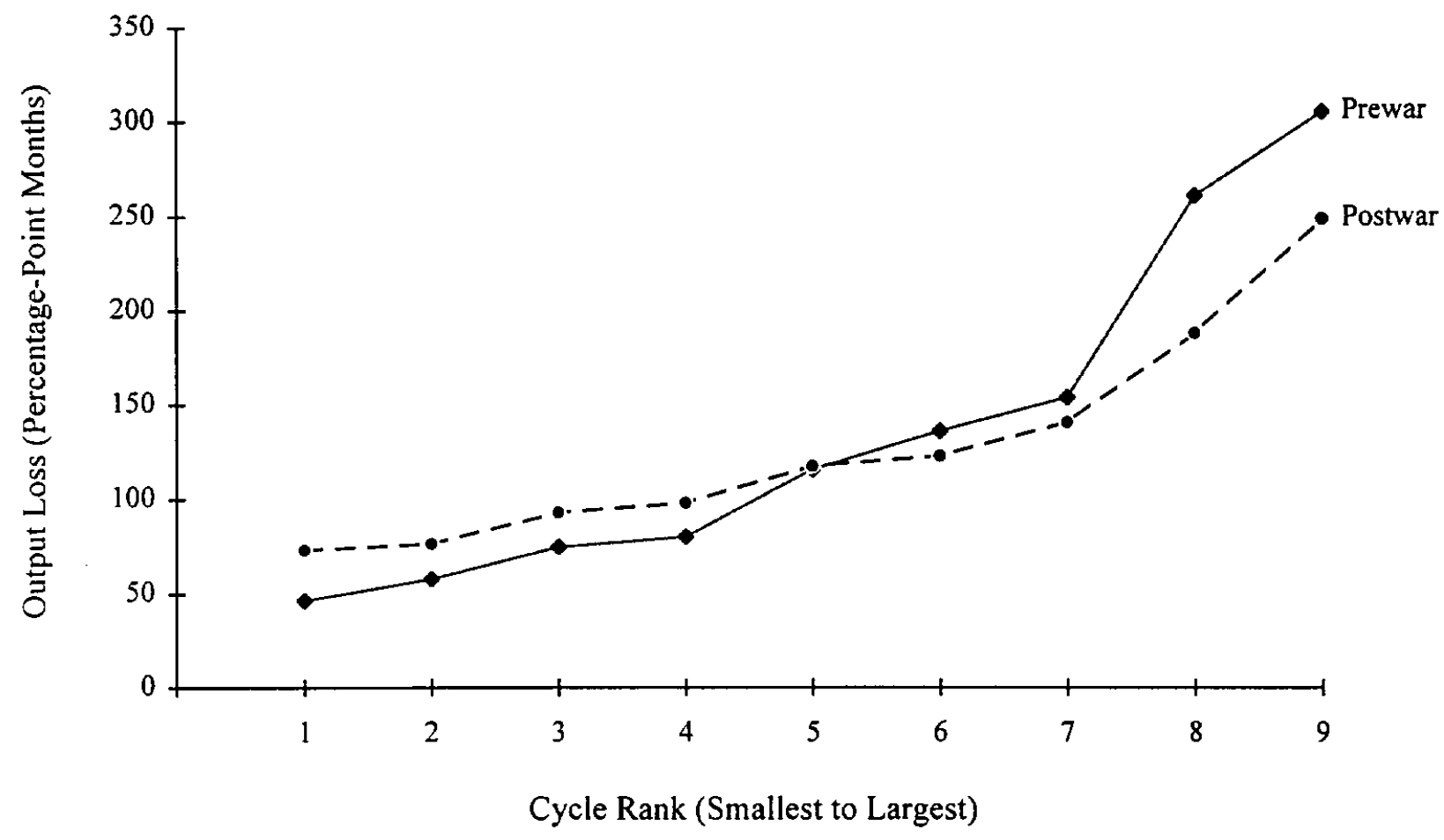


Figure 2

Effects of Discretionary Policy

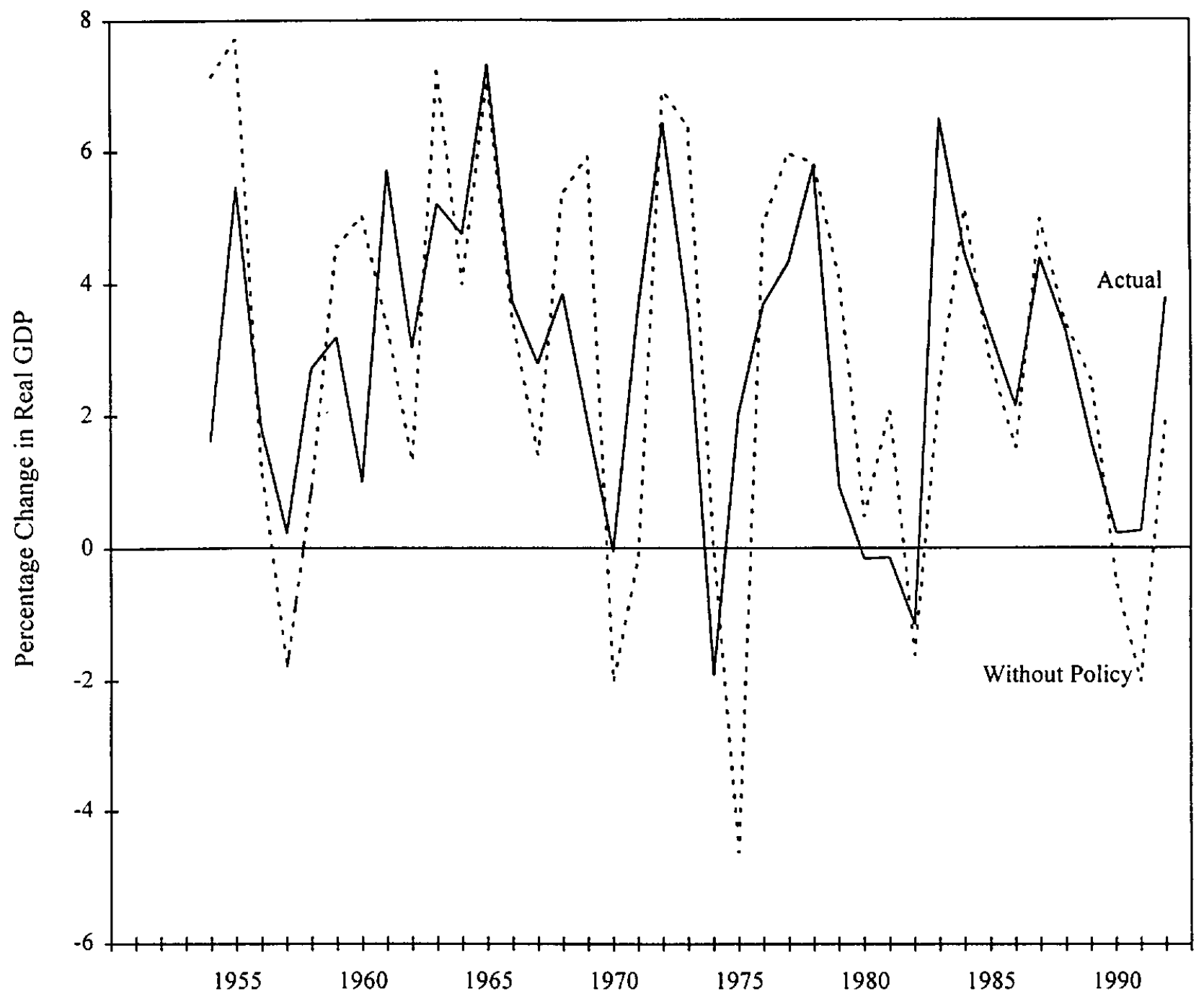


Table 1

Standard Deviation of Percentage Changes

\begin{tabular}{lccc}
\hline \multicolumn{1}{c}{ Series } & $1886-1916$ & $1920-1940$ & $1948-1997$ \\
\hline Industrial Production & $6.2 \%$ & $16.0 \%$ & $5.0 \%$ \\
GNP & 3.0 & 7.1 & 2.5 \\
Commodity Output & 5.2 & 9.0 & 4.9 \\
Unemployment Rate & 1.4 & & 1.1 \\
\hline
\end{tabular}

Notes: For the commodity output series, the interwar sample period stops in 1938. For the unemployment series, the prewar sample period covers only the period 1900-1916 and consistent interwar data are not available. The standard deviation for the unemployment rate is for simple changes and so is expressed in percentage points rather than percent. 
Table 2

Standard Deviation of Percentage Changes

\begin{tabular}{lcc}
\hline \multicolumn{1}{c}{ Series } & $1948-1984$ & $1985-1997$ \\
\hline Industrial Production & $5.7 \%$ & $2.2 \%$ \\
GNP & 2.8 & 1.3 \\
Commodity Output & 5.3 & 3.6 \\
Unemployment Rate & 1.2 & 0.6 \\
\hline
\end{tabular}

Notes: The standard deviation for the unemployment rate is for simple changes and so is expressed in percentage points rather than percent. 
Table 3

Dates of Peaks and Troughs

\begin{tabular}{|c|c|c|c|c|c|}
\hline \multicolumn{2}{|c|}{$\underline{1886-1916}$} & \multicolumn{2}{|c|}{$\underline{1920-1940}$} & \multicolumn{2}{|c|}{$\underline{1948-1997}$} \\
\hline Peak & Trough & Peak & Trough & Peak & Trough \\
\hline $1887: 2$ & $1887: 7$ & 1920:1 & 1921:3 & 1948:11 & 1949:10 \\
\hline 1893:1 & $1894: 2$ & $1923: 5$ & $1924: 7$ & $1953: 7$ & $1954: 5$ \\
\hline 1896:1 & 1897:1 & $1927: 3$ & $1927: 12$ & $1957: 8$ & $1958: 4$ \\
\hline 1900:4 & $1900: 12$ & $1929: 9$ & $1932: 7$ & 1960:4 & $1961: 2$ \\
\hline 1903:7 & $1904: 3$ & $1937: 8$ & $1938: 6$ & 1969:12 & 1970:11 \\
\hline $1907: 7$ & $1908: 6$ & $1939: 12$ & $1940: 3$ & $1973: 11$ & $1975: 3$ \\
\hline 1910:1 & 1911:5 & & & 1980:1 & $1980: 7$ \\
\hline 1914:6 & $1914: 12$ & & & $1981: 7$ & 1982:11 \\
\hline $1916: 5$ & $1917: 1$ & & & 1990:7 & 1991:3 \\
\hline
\end{tabular}

Notes: The set of dates that I derived for the pre-World War II era also includes a recession during the World War I gap with the peak in 1918:7 and the trough in 1919:3. The NBER dates include a recession during the World War II gap with the peak in 1945:2 and the trough in 1945:10. 
Table 4

Length of Recessions and Expansions

\begin{tabular}{|c|c|c|c|c|c|c|c|c|}
\hline \multicolumn{3}{|c|}{$\underline{1886-1916}$} & \multicolumn{3}{|c|}{$\underline{1920-1940}$} & \multicolumn{3}{|c|}{$\underline{1948-1997}$} \\
\hline $\begin{array}{l}\text { Year } \\
\text { of } \\
\text { Peak }\end{array}$ & $\begin{array}{c}\text { Mos. } \\
\text { to } \\
\text { Trough }\end{array}$ & $\begin{array}{l}\text { Mos. from } \\
\text { Trough } \\
\text { to Next } \\
\text { Peak }\end{array}$ & $\begin{array}{l}\text { Year } \\
\text { of } \\
\text { Peak }\end{array}$ & $\begin{array}{l}\text { Mos. } \\
\text { to } \\
\text { Trough }\end{array}$ & $\begin{array}{l}\text { los. from } \\
\text { Trough } \\
\text { to Next } \\
\text { Peak }\end{array}$ & $\begin{array}{l}\text { Year } \\
\text { of } \\
\text { Peak }\end{array}$ & $\begin{array}{l}\text { Mos. } \\
\text { to } \\
\text { Trough }\end{array}$ & $\begin{array}{c}\text { Mos. from } \\
\text { Trough } \\
\text { to Next } \\
\text { Peak }\end{array}$ \\
\hline 1887 & 5 & 66 & 1920 & 14 & 26 & 1948 & 11 & 45 \\
\hline 1893 & 13 & 23 & 1923 & 14 & 32 & 1953 & 10 & 39 \\
\hline 1896 & 12 & 39 & 1927 & 9 & 21 & 1957 & 8 & 24 \\
\hline 1900 & 8 & 31 & 1929 & 34 & 61 & 1960 & 10 & 106 \\
\hline 1903 & 8 & 40 & 1937 & 10 & 18 & 1969 & 11 & 36 \\
\hline 1907 & 11 & 19 & 1939 & 3 & & 1973 & 16 & 58 \\
\hline 1910 & 16 & 37 & & & & 1980 & 6 & 12 \\
\hline 1914 & 6 & 17 & & & & 1981 & 16 & 92 \\
\hline 1916 & 8 & & & & & 1990 & 8 & \\
\hline Avg. & 9.7 & 34.0 & Avg. & 14.0 & 31.6 & Avg. & 10.7 & 51.5 \\
\hline
\end{tabular}


Table 5

Output Loss

\begin{tabular}{cccccc}
\hline \multicolumn{2}{c}{$1886-1916$} & \multicolumn{2}{c}{$1920-1940$} & \multicolumn{2}{c}{$\underline{1948-1997}$} \\
$\begin{array}{c}\text { Year } \\
\text { of Peak }\end{array}$ & $\begin{array}{c}\text { Output } \\
\text { Loss }\end{array}$ & $\begin{array}{c}\text { Year } \\
\text { of Peak }\end{array}$ & $\begin{array}{c}\text { Output } \\
\text { Loss }\end{array}$ & $\begin{array}{c}\text { Year } \\
\text { of Peak }\end{array}$ & $\begin{array}{c}\text { Output } \\
\text { Loss }\end{array}$ \\
\hline 1887 & 57.8 & 1920 & 662.7 & 1948 & 117.4 \\
1893 & 260.1 & 1923 & 188.2 & 1953 & 122.5 \\
1896 & 135.6 & 1927 & 67.9 & 1957 & 140.1 \\
1900 & 80.1 & 1929 & 3120.0 & 1960 & 93.0 \\
1903 & 115.5 & 1937 & 579.8 & 1969 & 98.0 \\
1907 & 304.3 & 1939 & 64.7 & 1973 & 248.1 \\
1910 & 153.3 & & & 1980 & 73.1 \\
1914 & 74.6 & & & 1981 & 187.4 \\
1916 & 46.3 & & & 1990 & 76.4 \\
& & & & & Avg. \\
Avg. & 136.4 & Avg. & 780.6 & & 128.4 \\
\hline
\end{tabular}

Notes: Output loss is the sum of the percentage shortfall of industrial production from its peak level in each month between the peak and the return to peak. It is thus measured in percentage-point-months. 
Table 6

Contribution of Monetary Shocks

\begin{tabular}{cccc}
\hline $\begin{array}{c}\text { Year of } \\
\text { Real Decline }\end{array}$ & $\begin{array}{c}\text { Change in } \\
\text { Industrial } \\
\text { Production }\end{array}$ & $\begin{array}{c}\text { Date of } \\
\text { Monetary Shock }\end{array}$ & $\begin{array}{c}\text { Change in Industrial } \\
\text { Production Without } \\
\text { Monetary Shocks }\end{array}$ \\
\hline 1949 & $-4.2 \%$ & Oct. 1947 & $1.8 \%$ \\
1953 & $-5.0 \%$ & --- & $-5.0 \%$ \\
1957 & $-7.0 \%$ & Sept. 1955 & $-1.0 \%$ \\
1960 & $-6.6 \%$ & --- & $-6.6 \%$ \\
1970 & $-4.0 \%$ & Dec. 1968 & $1.8 \%$ \\
1974 & $-8.0 \%$ & Apr. 1974 & $-5.5 \%$ \\
$1979-1982$ & $-9.6 \%$ & Aug. 1978 and Oct. 1979 & $9.3 \%$ \\
1990 & $-2.1 \%$ & Dec. 1988 & $3.6 \%$ \\
Avg. of 11 Years & $-4.2 \%$ & & $-0.1 \%$ \\
\hline
\end{tabular}

Notes: The change in industrial production without monetary shocks is the same as the actual change in 1953 and 1960 because there were no monetary shocks near those years. Both the actual and simulated changes in industrial production are calculated as the sum of monthly changes and thus represent the change from December of the previous year to December of the year identified. 